GRASAS Y ACEITES 65 (1)

January-March 2014, e011

ISSN-L: 0017-3495

doi: http://dx.doi.org/10.3989/gya.073913

\title{
The effects of cultivar and harvest year on the fatty alcohol composition of olive oils from Southwest Calabria (Italy)
}

\author{
A.M. Giuffrè \\ Università degli Studi Mediterranea di Reggio Calabria (Italy) - Dipartimento di Agraria. \\ Corresponding author: amgiuffre@unirc.it.
}

Submitted: 8 July 2013; Accepted: 28 October 2013; Published on line: 13/02/2014

SUMMARY: The fatty alcohol (FAL) composition of olive oils produced in Southwest Calabria (Southern Italy) was analyzed over three harvest years 2005-2006-2007. Three autochthonous cultivars: Cassanese, Ottobratica, Sinopolese and seven allochtonous cultivars: Coratina, Itrana, Leccino, Nocellara Messinese, Nociara, Pendolino and Picholine were considered. Hexacosanol was always the main FAL occurring in the olive oil. The autochthonous cultivars were among those with the highest total FAL contents. Nevertheless, both autochthonous and allochthonous cultivars produced olive oil within the limit indicated by EU and IOC regulations. Cultivar affected the FAL content highly significantly or very highly significantly, whereas in a large part of the cases the harvest year did not influence the FAL content. Cultivar $\mathrm{x}$ harvest year influenced highly significantly or very highly significantly only $\mathrm{C}_{22-\mathrm{OH}}, \mathrm{C}_{23-\mathrm{OH}}, \mathrm{C}_{24-\mathrm{OH}}, \mathrm{C}_{25-\mathrm{OH}}$, odd chain FALs and the ratio even chain/odd chain FALs.

KEYWORDS: Fatty alcohols; Minor components; Olive oil; Policosanols; Unsaponifiable

RESUMEN: Efectos de la variedad y año de cosecha sobre la composición de alcoholes grasos de aceites de oliva del Suroeste de Calabria (Italia). Se ha analizado, durante tres cosechas 2005-2006-2007, la composición de alcoholes grasos (FAL) de aceites de oliva producidos en el suroeste de Calabria (sur de Italia). Se consideraron tres cultivares autóctonos: Cassanese, Ottobratica y Sinopolese y siete alóctonas: Coratina, Itrana, Leccino, Nocellara Messinese, Nociara, Pendolino y Picholine. Hexacosanol fue siempre el principal FAL en los aceites de oliva. Los cultivares autóctonos se encuentran entre los de mayor contenido total de FAL. No obstante, ambos cultivares, autóctonos y alóctonos producen aceites de oliva dentro de los límites de los reglamentos de la UE y del COI. Los cultivares afectan de manera altamente significativa o muy significativa al contenido de FAL, mientras que el año de cosecha no influyó en el contenido de FAL. Cultivar x año de cosecha influye de manera altamente significativa o muy significativa sobre $\mathrm{C}_{22-\mathrm{OH}}, \mathrm{C}_{23-\mathrm{OH}}, \mathrm{C}_{24-\mathrm{OH}}, \mathrm{C}_{25-\mathrm{OH}}$, al total de alcoholes grasos de cadena impar y a la relación: FALs cadena par/FALcadena impar.

PALABRAS CLAVE: Aceite de oliva; Alcoholes grasos; Componentes menores; Insaponificable; Policosanoles

Citation/Cómo citar este artículo: Giuffrè AM. 2014. The effects of cultivar and harvest year on the fatty alcohol composition of olive oils from Southwest Calabria (Italy). Grasas Aceites 65 (1): e011. doi: http://dx.doi.org/10.3989/gya.073913

Copyright: (c) 2014 CSIC. This is an open-access article distributed under the terms of the Creative Commons Attribution-Non Commercial (by-nc) Spain 3.0 Licence. 


\section{INTRODUCTION}

Olive oil is mainly composed of glyceridic components (Giuffrè, 2013a) and minor components such as sterols (Giuffrè, 2012; Giuffrè et al., 2012; Giuffrè and Louadj, 2013), waxes (Giuffrè, 2013b), polyphenols and tocopherols, which are generally used to characterize a mono-cultivar olive oil and to evaluate its chemical quality. Fatty alcohols (FALs) are contained in the minor component fraction and in particular in the unsaponifiable fraction. FALs are a useful parameter for classifying different categories of olive oil: oils with a wax content of between $300 \mathrm{mg} \cdot \mathrm{kg}^{-1}$ and $350 \mathrm{mg} \cdot \mathrm{kg}^{-1}$ are considered to be lampante olive oil if the total aliphatic alcohol content is less than or equal to $350 \mathrm{mg} \cdot \mathrm{kg}^{-1}$; oils with a wax content of between $300 \mathrm{mg} \mathrm{kg}^{-1}$ and $350 \mathrm{mg} \cdot \mathrm{kg}^{-1}$ are considered to be crude olive-pomace oil if the total aliphatic alcohol content is above $350 \mathrm{mg} \cdot \mathrm{kg}^{-1}$ and if the erythrodiol and uvaol content is greater than $3.5 \%$ (EU, 2011; IOC, 2012). Grob et al. (1990) found a fatty alcohol content in raw solvent-extracted olive oils $\left(725 \mathrm{mg} \cdot \mathrm{kg}^{-1}\right)$ ten times higher than in extra virgin olive oil (73 and $61 \mathrm{mg} \cdot \mathrm{kg}^{-1}$ ). All FALs otherwise known as aliphatic alcohols in olive oil are a mixture of long chain fatty alcohols known as policosanols. The majority of these are even chain fatty alcohols (ECFALs): $\mathrm{C}_{22-\mathrm{OH}}, \mathrm{C}_{24-\mathrm{OH}}, \mathrm{C}_{26-\mathrm{OH}}$, and $\mathrm{C}_{28-\mathrm{OH}}$. Odd chain fatty alcohols (OCFALs) are present in minor amounts: $\mathrm{C}_{23-\mathrm{OH}}, \mathrm{C}_{25-\mathrm{OH}}$, and $\mathrm{C}_{27-\mathrm{OH}}$.

It is worth noting that the FAL composition changes in olive oil during ripe table olive processing with a decrease in docosanol and a substantial increase in octacosanol (López-López et al., 2009). Octacosanol is the most common in olive oil extracted from commercial table olives of different cultivars processed by Spanish / Sevillian style, or untreated and directly brined with a limited fermentation, or by California style (López-López et al., 2008). Octacosanol is very effective in lowering LDL and increasing HDL (Taylor et al., 2003). In addition, it has been shown that policosanol is as effective as aspirin in terms of its antiaggregatory effects. Octacosanol also offers cytoprotective effects. This affords an opportunity for octacosanol to be taken as an alternative to aspirin in patients who have a history of or suffer from gastric irritation (Taylor et al., 2003).

The aim of this paper was to study the fatty alcohol composition (docosanol $\mathrm{C}_{22-\mathrm{OH}}{ }^{-}$tricosanol $\mathrm{C}_{23-\mathrm{OH}}{ }^{-}$ tetracosanol $\mathrm{C}_{24-\mathrm{OH}}$ - pentacosanol $\mathrm{C}_{25-\mathrm{OH}}$ - hexacosanol $\mathrm{C}_{26-\mathrm{OH}}$ - heptacosanol $\mathrm{C}_{27-\mathrm{OH}}$ - octacosanol $\mathrm{C}_{28-\mathrm{OH}}$ ECFALs - OCFALs - total FALs) of pressed olive oil from autochthonous and allochthonous olive cultivars growing in Southwest Calabria (Southern Italy), on the basis of the European (EU, 2011) and the I.O.C. (IOC, 2012) regulations. Particular emphasis was placed on the effect of cultivar and harvest year on fatty alcohol composition.
To our knowledge this is the first report to show the effects of cultivar and harvest year on fatty alcohol composition of olive oils from cultivars grown in Southwest Calabria (Southern Italy).

\section{MATERIALS AND METHODS}

\subsection{Plant material and extraction procedure}

The experiments were conducted over three harvest years 2005, 2006 and 2007 with the Cassanese, Coratina, Itrana, Leccino, Nociara, Ottobratica, Pendolino, Picholine and Sinopolese cultivars. The Nocellara Messinese cultivar was studied only in the 2005 harvest year. Cassanese, Ottobratica and Sinopolese are commonly cultivated in the Calabria Region (Southern Italy) for oil extraction. The other examined cultivars are allochthonous for this region. Olive trees were well managed and had no nutrient deficiency or pest damage. Fifteen 25-40 year old trees per cultivar were selected and labeled in mono-cultivar groves, situated in the area of Rizziconi (Southwest Calabria). This area, at an altitude of $100 \mathrm{~m}$ above sea level, is characterized by damp and rainy winters and hot summers. Each mono-cultivar grove was at least $3 \mathrm{~km}$ from the others. Olive sampling was conducted at biweekly intervals from October, when the fruit was $20 \%$ ripe, until fruit was no longer found on the trees. Freshly and manually harvested drupes (40 kg approximately per cultivar, $2,5 \mathrm{~kg}$ approximately per tree) were placed in a plastic container and immediately transported to the laboratory where they were cleaned to eliminate twigs and leaves and were washed in fresh water to remove dust. At this point, the olives were immediately processed in a laboratory mill "Mini 30" (AGRIMEC Valpesana, Calzaiolo, S. Casciano VP, Florence), with a capacity of $40 \mathrm{~kg}$. First the olives were crushed with a hammer-mill. The resulting paste was mixed at a temperature between 15 and $20{ }^{\circ} \mathrm{C}$ for 35 minutes, then placed between a pile of circular metallic grids and pressed using a hydraulic press with a mild and continuous increase in pressure up to 200 bars. The liquid phase was submitted to separation by centrifugation and the obtained oil was filtered through filter paper. The oil was kept in $100 \mathrm{~mL}$ amber glass bottles and maintained in dark conditions at $15-20^{\circ} \mathrm{C}$, until analysis.

\subsection{Chemicals}

Standard samples of 1-docosanol (behenyl alcohol), 1-tricosanol (tricosyl alcohol), 1-tetracosanol (lignoceryl alcohol), 1-heptacosanol, 1-octacosanol (octacosoyl alcohol) from Sigma-Aldrich (St. Louis, MO (USA), and 1-pentacosanol (pentacosoyl alcohol) from $\mathrm{GmbH}$ (Germany), and 1-hexacosanol (ceryl alcohol) from J\&K scientific Ltd. (China) were used as references. TLC silica gel plates were 
from Merck S.p.A., (Milan, Italy). All other reagents were from Carlo Erba, (Milan, Italy).

\subsection{Methods}

\subsubsection{Determination of fatty alcohols}

FAL composition was determined as described in Annex XIX of the Consolidated Text on the characteristics of olive oil and olive-residue oil and on the relevant methods of analysis CONSLEG 2003 (CONSLEG, 2003). Olive oil (5g) was saponified with a $2 \mathrm{M}$ ethanolic potassium hydroxide solution, using eicosanol $\left(\mathrm{C}_{20-\mathrm{OH}}\right)$ as an internal standard; after boiling, $50 \mathrm{~mL}$ of distilled water was added. The reaction mixture was extracted three times with ethyl ether. The three ether extracts were introduced into a separating funnel and washed with distilled water $(50 \mathrm{~mL}$ each time) until reaching a neutral reaction. The organic extracts were dried with anhydrous sodium sulphate and filtered. These extracts were evaporated to dryness using a rotary evaporator. The remaining residue was dissolved in $2 \mathrm{~mL}$ of chloroform, and then the FAL fraction was separated by TLC using a plate-developing chamber which contained hexane/diethyl ether 60:40 (v/v). After TLC separation, the silica plate was sprayed lightly and uniformly with 2,7-dichlorofluorescein. The FAL fraction was separated from the unsaponifiable extract by chromatography on a basic silica gel plate. The FALs recovered from the silica gel were transformed into trimethyl silyl ethers and analyzed by a gas chromatograph Perkin Elmer, Model 8600. The working conditions were: carrier gas (helium) $10 \mathrm{psi}$ of pressure, auxiliary gas (hydrogen at $15 \mathrm{psi}$ and air at $22 \mathrm{psi}$ ), split/splitless injector (operating in the split mode) temperature $\left(280^{\circ} \mathrm{C}\right)$, flame ionization detector (F.I.D.) temperature $\left(290^{\circ} \mathrm{C}\right)$, a capillary column SE 54 (30 m length $\times 0.32 \mathrm{~mm}$ ID, $0.5 \mu \mathrm{m}$ film thickness, Mega, Milan - Italy) and an injection volume of $1 \mu \mathrm{L}$. The temperature program used for the analysis was as follows: initial temperature as set at $180{ }^{\circ} \mathrm{C}$, held for $2 \mathrm{~min}$, and ramped at $2^{\circ} \mathrm{C} \cdot \mathrm{min}^{-1}$ to $260{ }^{\circ} \mathrm{C}$ held for $15 \mathrm{~min}$ and ramped at $6{ }^{\circ} \mathrm{C} \cdot \mathrm{min}^{-1}$ to $270^{\circ} \mathrm{C}$. The identification of the compounds was based on a comparison of retention indices with those of standard samples and with literature data.

\subsubsection{Statistical analysis}

SPSS 15.0 software was used to determine the significant differences for all parameters. Two effects were taken into consideration, the cultivar and the harvest year. Data were analyzed by one-way and two-way analyses of variance (ANOVA) at 5\% significance level and regression analysis. The Duncan test was used to determine the differences between cultivars. Bar graphs were constructed with Excel 2003.

\section{RESULTS AND DISCUSSION}

\subsection{Fatty alcohol composition}

In Tables 1 and 2 the different contents of FALs found in the ten studied cultivars are reported. The highest value of $\mathrm{C}_{22-\mathrm{OH}}$ was found in Ottobratica (21.47 $\pm 11.61 \mathrm{mg} \cdot \mathrm{kg}^{-1}$ ) accounting for $15.51 \%$ of the total FALs, followed by Pendolino and Sinopolese (with $13.93 \pm 0.52 \mathrm{mg} \cdot \mathrm{kg}^{-1}$ and $12.86 \pm 7.56 \mathrm{mg} \cdot \mathrm{kg}^{-1}$, respectively), Coratina represented the lowest content with $4.40 \mathrm{mg} \cdot \mathrm{kg}^{-1}$. The $\mathrm{C}_{22-\mathrm{OH}}$ varied from $6.32 \%$ (Coratina) to $16.04 \%$ (Nocellara Messinese) in all the studied cultivars. The $\mathrm{C}_{23-0 \mathrm{H}}$ content was the highest in Sinopolese $\left(3.33 \pm 3.06 \mathrm{mg} \mathrm{kg}^{-1}\right)$ and the lowest in Itrana $\left(0.87 \pm 0.35 \mathrm{mg} \cdot \mathrm{kg}^{-1}\right) . \mathrm{C}_{23-\mathrm{OH}}$ accounted for $0.93 \%-3.01 \%$ of the total FALs in all the studied cultivars. The $\mathrm{C}_{24-\mathrm{OH}}$ was lowest in Nocellara Messinese $6.71 \pm 1.58 \mathrm{mg} \cdot \mathrm{kg}^{-1}$ and highest in Pendolino $\left(36.00 \pm 8.54 \mathrm{mg} \cdot \mathrm{kg}^{-1}\right)$, 5.36 times more and ranged from $14.84 \%$ of Coratina, to $31.13 \%$ of Pendolino. The greatest content of $\mathrm{C}_{25-\mathrm{OH}}$ was observed in Cassanese with $8.80 \pm 5.00 \mathrm{mg} \cdot \mathrm{kg}^{-1}(10.13 \%$ of the total FALs), the lowest content was detected in Nocellara Messinese with $1.56 \pm 0.58 \mathrm{mg} \cdot \mathrm{kg}^{-1}$ ( $4.63 \%$ of the total FALs).

$\mathrm{C}_{26-\mathrm{OH}}$ always made up the highest percentage and gave the highest quantity of all fatty alcohols in the cultivars studied. In particular, the highest content was found in Sinopolese $\left(47.80 \pm 20.68 \mathrm{mg} \mathrm{kg}^{-1}\right)$ and the lowest content was found in Nocellara Messinese $\left(12.75 \pm 11.19 \mathrm{mg} \cdot \mathrm{kg}^{-1}\right)$. By considering the results as a percentage, $\mathrm{C}_{26-\mathrm{OH}}$ was the highest in Coratina $(46.08 \%)$ and the lowest in Ottobratica $(27.34 \%)$. It was observed that $\mathrm{C}_{27-\mathrm{OH}}$ was always lower than $3.33 \mathrm{mg} \mathrm{kg}^{-1}$ in Ottobratica and accounted for less of $3.93 \%$ in Nociara.

$\mathrm{C}_{28-0 \mathrm{O}}$, ranged between a minimum of $10.03 \pm 9.78$ $\mathrm{mg} \cdot \mathrm{kg}^{-1}$ in Nocellara Messinese and a maximum of $30.53 \pm 13.42 \mathrm{mg} \cdot \mathrm{kg}^{-1}$ in Ottobratica (three times more).

In all cases, ECFALs were in higher amounts than OCFALs with the maximum ratio in Pendolino $(15.24 \pm 2.46)$ and in Leccino $(13.19 \pm 8.87)$ and the minimum ratio in Cassanese $(5.43 \pm 2.02)$. The greatest amounts of ECFALs were found in Ottobratica $\left(119.94 \pm 43.10 \mathrm{mg} \cdot \mathrm{kg}^{-1}, 91.61 \%\right)$, in Pendolino (116.93 $\left.\pm 66.16 \mathrm{mg} \cdot \mathrm{kg}^{-1}, 93.61 \%\right)$ and in Sinopolese $\left(112.40 \pm 30.44 \mathrm{mg} \cdot \mathrm{kg}^{-1}, 90.82 \%\right)$. OCFALs were found in the highest amount in Cassanese $\left(13.86 \pm 5.63 \mathrm{mg} \cdot \mathrm{kg}^{-1}, \quad 16.07 \%\right)$ and in the lowest quantity in Nocellara Messinese $\left(3.44 \pm 1.56 \mathrm{mg} \cdot \mathrm{kg}^{-1}, 9.93 \%\right)$. Total FALs varied to a large extent according to cultivars, showing the highest amounts in Ottobratica $\left(130.40 \pm 45.16 \mathrm{mg} \cdot \mathrm{kg}^{-1}\right)$, in Pendolino $\left(124.60 \pm 70.28 \mathrm{mg} \cdot \mathrm{kg}^{-1}\right)$, in Sinopolese $\left(123.73 \pm 32.49 \mathrm{mg} \cdot \mathrm{kg}^{-1}\right)$ and the lowest amount in 


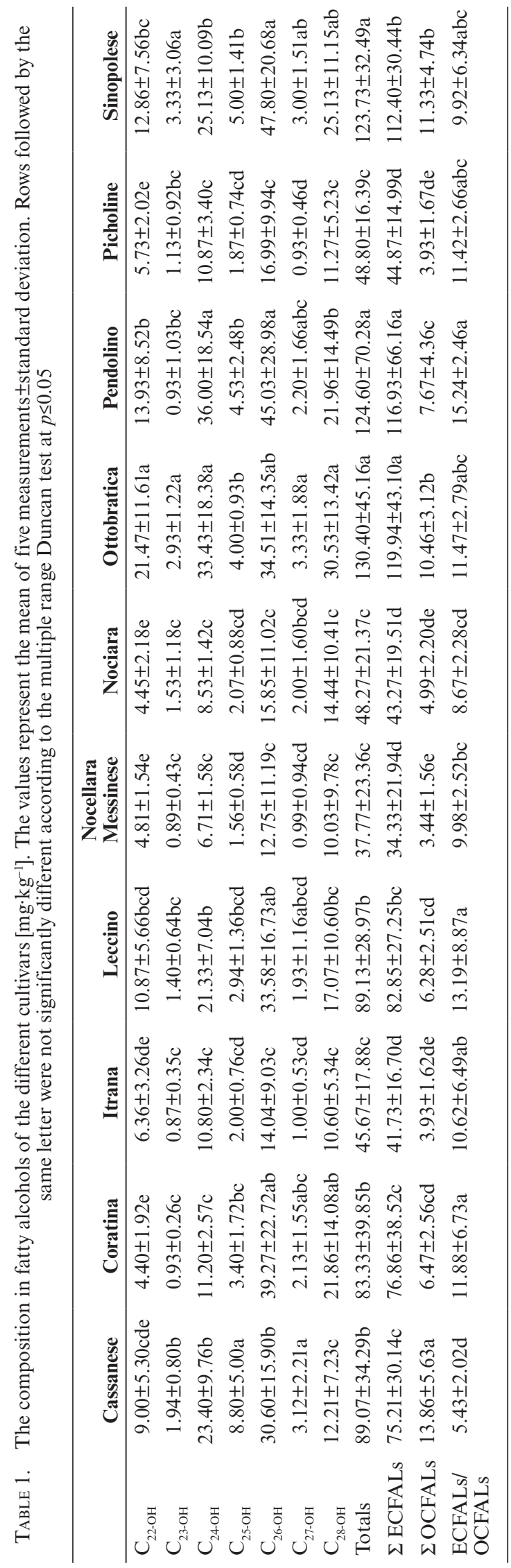

Nocellara Messinese $\left(37.77 \pm 23.36 \mathrm{mg} \cdot \mathrm{kg}^{-1}\right)$, about 3.45 times less than in Ottobratica. The total FALs found in Picholine cultivated in South West Calabria $\left(48.80 \pm 16.39 \mathrm{mg} \mathrm{kg}^{-1} \mathrm{~kg}\right.$ ) were around the lower limit of the total FAL content revealed in Picholine Marocaine and Picholine Languedoc found in olive oil produced in Morocco with an FAL content ranging between $46.0 \mathrm{mg} \cdot \mathrm{kg}^{-1}$ and $96.0 \mathrm{mg} \cdot \mathrm{kg}^{-1}$ (El Antari et al., 2000).

Similarly for Calabrian olive oils, Krichène et al. (2010) have found $\mathrm{C}_{26-\mathrm{OH}}$ to be the most common FAL in virgin olive oil from Jdallou, Chemlali Sfax, Swabâa, El Hor, and Oueslati monovarietal Tunisian cultivars. Also Strabbioli et al. (2007) have found $\mathrm{C}_{26-\mathrm{OH}}$ to be the greatest FAL component in the olive oil of cultivars grown in Central Italy, including the Leccino cultivar. Moreover, hexacosanol was found to be prominent in Coratina from the Apulia Region in the Southeast of Italy, in Koroneki from Crete (Aparicio and Luna, 2002), in Manzanilla cv., Picual cv. and Gordal cv. in the region of the Guadalquivir valley, Encinarejo (Córdoba - Spain), (Orozco-Solano et al., 2010) and in pomace olive oil (Fernández-Arche et al., 2009).

In the olive oil from cultivars grown in Central Italy, Ranalli et al. (2002) found much higher results (500 $\mathrm{mg} \mathrm{kg}^{-1}$ in total FALs) than were found for the olive oils produced in Southwest Calabria. In the olive oil of Coratina grown in Apulia, Aparicio and Luna (2002) found a total FAL content of 63 $\mathrm{mg} \cdot \mathrm{kg}^{-1}$ (after two phase extraction) and $58 \mathrm{mg} \cdot \mathrm{kg}^{-1}$ (after three phase extraction): less than for the Coratina oil of Southwest Calabria (83.33 \pm 39.85$)$.

\subsection{Analysis of variance}

The one-way ANOVA results are reported in Table 1. Significant differences $(p \leq 0.05)$ among cultivars were found for several fatty alcohols. Ottobratica differs significantly for $\mathrm{C}_{22-\mathrm{OH}}$. With regards to $\mathrm{C}_{24-\mathrm{OH}}$ there were significant differences among Ottobratica, Pendolino and Coratina, Itrana, Nocellara Messinese, Nociara, Picholine. In the case of $\mathrm{C}_{28-\mathrm{OH}}$ there were significant differences among Coratina, Ottobratica, Sinopolese and Cassanese, Itrana, Leccino, Nocellara Messinese, Nociara, Picholine. With regards to total FAL contents there were significant differences among Ottobratica, Pendolino, Sinopolese and Itrana, Nocellara Messinese, Nociara, Picholine. Cassanese had the highest significant OCFAL content. Tricosanol, pentacosanol, hexacosanol, heptacosanol, octacosanol, total FALs and ECFALs/ OCFALs did not differ significantly for Ottobratica and Sinopolese, two autochthonous cultivars, meaning these two cultivars were the most similar with regards to their fatty alcohol content.

The results of two-way ANOVA are reported in Table 3. Cultivars showed a highly 
The effects of cultivar and harvest year on the fatty alcohol composition of olive oils from Southwest Calabria (Italy) 5

TABLE 2. Percentage compositions in fatty alcohols of the different cultivars. The values represent the mean of fifteen samples

\begin{tabular}{lcrrrrrrrrr}
\hline & Cassanese & Coratina & Itrana & Leccino & $\begin{array}{c}\text { Nocellara } \\
\text { Messinese }\end{array}$ & Nociara & Ottobratica & Pendolino & Picholine & Sinopolese \\
\hline $\mathrm{C}_{22-\mathrm{OH}}$ & 10.88 & 6.32 & 15.05 & 13.11 & 16.04 & 12.08 & 15.51 & 12.00 & 12.83 & 11.99 \\
$\mathrm{C}_{23-\mathrm{OH}}$ & 2.31 & 1.29 & 1.92 & 1.66 & 3.01 & 2.38 & 2.48 & 0.93 & 1.96 & 2.91 \\
$\mathrm{C}_{24-\mathrm{OH}}$ & 26.62 & 14.84 & 24.23 & 25.14 & 20.79 & 21.65 & 25.25 & 31.13 & 24.36 & 21.78 \\
$\mathrm{C}_{25-\mathrm{OH}}$ & 10.13 & 4.46 & 4.24 & 3.27 & 4.63 & 4.29 & 3.33 & 3.86 & 3.76 & 3.84 \\
$\mathrm{C}_{26-\mathrm{OH}}$ & 33.19 & 46.08 & 30.38 & 36.80 & 30.36 & 30.13 & 27.34 & 33.89 & 33.02 & 37.06 \\
$\mathrm{C}_{27-\mathrm{OH}}$ & 3.63 & 2.29 & 2.09 & 2.06 & 2.30 & 3.93 & 2.58 & 1.60 & 2.03 & 2.38 \\
$\mathrm{C}_{28-\mathrm{OH}}$ & 13.23 & 24.72 & 22.09 & 17.97 & 22.88 & 25.54 & 23.52 & 16.58 & 22.05 & 20.02 \\
$\Sigma$ ECFALs & 83.92 & 91.96 & 91.74 & 93.01 & 90.07 & 89.39 & 91.61 & 93.61 & 92.25 & 90.82 \\
$\Sigma$ OCFALs & 16.07 & 8.04 & 8.26 & 6.99 & 9.93 & 10.61 & 8.39 & 6.39 & 7.75 & 9.13 \\
ECFALs/OCFALs & 5.22 & 11.44 & 11.11 & 13.30 & 9.07 & 8.42 & 10.92 & 14.65 & 11.90 & 9.75 \\
\hline
\end{tabular}

TABLE 3. Fatty alcohols with significant differences.

ANOVA experiment: cultivar, harvest year, cultivar $\times$ harvest year. ${ }^{* * *}(p \leq 0.001) ; * *(p \leq 0.01) ; *(p \leq 0.05) ;$ n.s., not significant $(p>0.05)$. Each result is calculated as the mean of five different replicates for each harvest year

\begin{tabular}{|c|c|c|c|}
\hline Fatty alcohols & Cultivar & Harvest year & $\begin{array}{c}\text { Cultivar } \\
\text { X } \\
\text { Harvest year }\end{array}$ \\
\hline $\mathrm{C}_{22-\mathrm{OH}}$ & $* * *$ & $* *$ & $* *$ \\
\hline $\mathrm{C}_{23-\mathrm{OH}}$ & $* *$ & n.s. & $* * *$ \\
\hline $\mathrm{C}_{24-\mathrm{OH}}$ & $* * *$ & n.s. & $* * *$ \\
\hline $\mathrm{C}_{25-\mathrm{OH}}$ & $* * *$ & n.s. & $* * *$ \\
\hline $\mathrm{C}_{26-\mathrm{OH}}$ & $* * *$ & n.s. & n.s. \\
\hline $\mathrm{C}_{27-\mathrm{OH}}$ & $* *$ & n.s. & n.s. \\
\hline $\mathrm{C}_{28-\mathrm{OH}}$ & $* * *$ & n.s. & n.s. \\
\hline $\begin{array}{r}\text { Total Fatty } \\
\text { Alcohols }\end{array}$ & $* * *$ & n.s. & n.s. \\
\hline ECFAs & $* * *$ & n.s. & n.s. \\
\hline OCFAs & $* * *$ & n.s. & $* * *$ \\
\hline ECFAs/OCFAs & $* *$ & $* *$ & $* *$ \\
\hline
\end{tabular}

significant effect $(p \leq 0.01)$ for tricosanol, heptacosanol and for ECFALs/OCFALs and a very highly significantly effect $(p \leq 0.001)$ for all other parameters. Harvest year had a highly significant effect $(p \leq 0.01)$ for docosanol and for ECFLAs/OCFALs and no significant effect $(p>0.05)$ for all other FALs singularly considered, ECFALs, OCFALs and for ECFALs/OCFALs. Cultivar x harvest year had a highly significant effect $(p \leq 0.01)$ for docosanol and ECFLAs/OCFALs, and a very highly significantly effect $(p \leq 0.001)$ for tricosanol, tetracosanol, pentacosanol and OCFALs, and no significant effect $(p>0.05)$ for hexacosanol, heptacosanol, octacosanol, total FALs or ECFALs.

\subsection{Bar graphs}

The $\mathrm{C}_{22-\mathrm{OH}}$ contents in the three studied harvest years are reported in Figure 1. Leccino showed the maximum content in 2005 and a lowest content in the two subsequent harvest years, approximately $50 \%$ less. Pendolino had an increasing trend from 2005 to 2007. All other cultivars showed the highest contents in 2006.

The concentration in $\mathrm{C}_{23-\mathrm{OH}}$ is depicted in Figure 2. Cassanese, Itrana and Nociara had an increasing trend from the first to the third harvest year. No tricosanol content or trace amounts were found in Pendolino or in Sinopolese in the second harvest year and in Picholine in the first harvest year. Coratina, Leccino and Ottobratica had the lowest concentration in 2006.

The concentration in $\mathrm{C}_{24-\mathrm{OH}}$ is depicted in Figure 3. Leccino confirmed the trend found for $\mathrm{C}_{22-\mathrm{OH}}$. Cassanese and Pendolino had an increasing trend from 2005 to 2007, whereas tetracosanol in Nociara and Ottobratica decreased over the three harvest years. In the remaining cultivars the maximum content was in 2006.

The concentration in $\mathrm{C}_{25-\mathrm{OH}}$ is depicted in Figure 4. The pentacosanol content increases from 2005 to 2007 in Cassanese, Itrana, Pendolino and Picholine, whereas in Nociara and Sinopolese it decreases. In Coratina and Leccino the highest content was in 2006.

$\mathrm{The}_{26-\mathrm{OH}}$ contentis shownin Figure 5. Hexacosanol increased from 2005 to 2007 in Cassanese, Nociara, Ottobratica, Pendolino and Picholine. Only Coratina had a decreasing trend.

The variation in $\mathrm{C}_{27-\mathrm{OH}}$ content is compared in Figure 6. The maximum accumulation for Leccino, Nociara, Ottobratica and Pendolino was found in 2006. Heptacosanol decreased in Coratina over the three studied harvest years.

The $\mathrm{C}_{28-\mathrm{OH}}$ content is presented in Figure 7 . Itrana, Ottobratica, Pendolino and Picholine had 


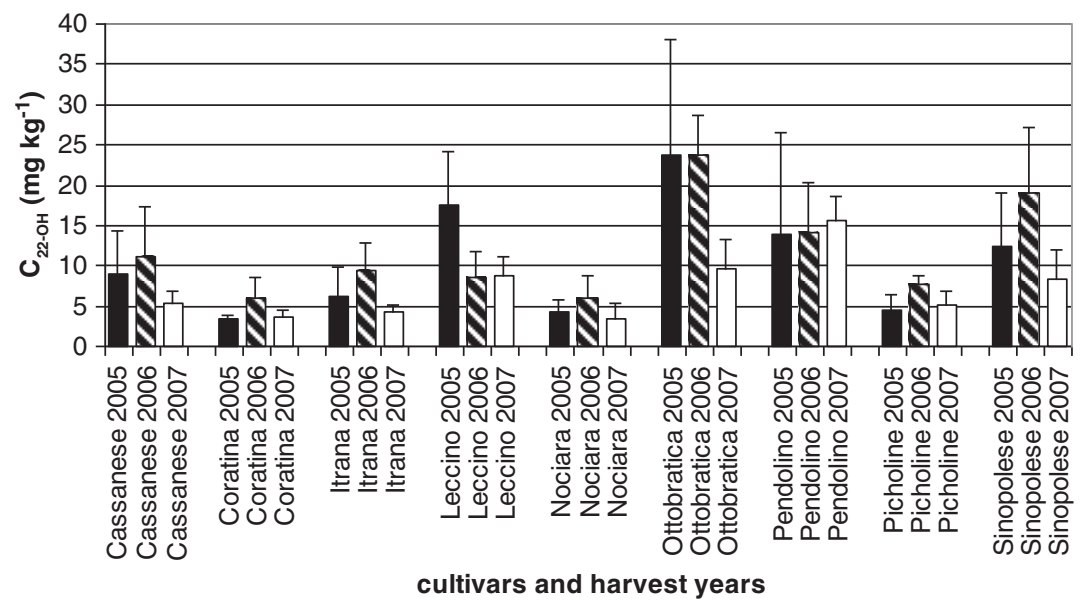

FIGURE 1. Variation in $\mathrm{C}_{22-\mathrm{OH}}$ content for three harvest years 2005, 2006 and 2007, for the different cultivars. The values represent the means of five measurements \pm standard deviation.

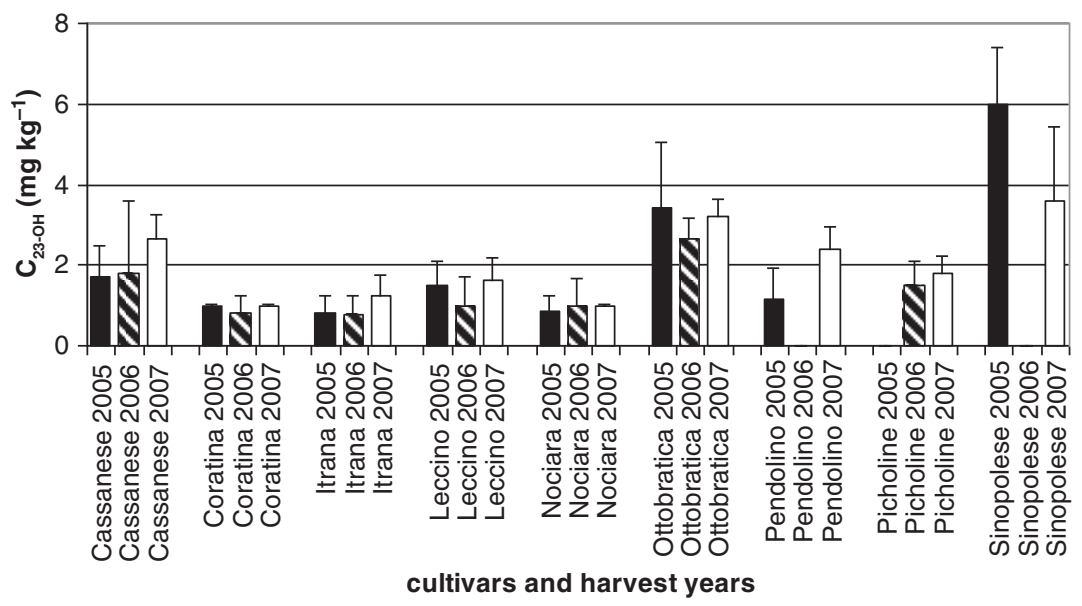

FIGURE 2. Variation in $\mathrm{C}_{23-\mathrm{OH}}$ contents for three harvest years 2005, 2006 and 2007, for the different cultivars. The values represent the means of five measurements \pm standard deviation.

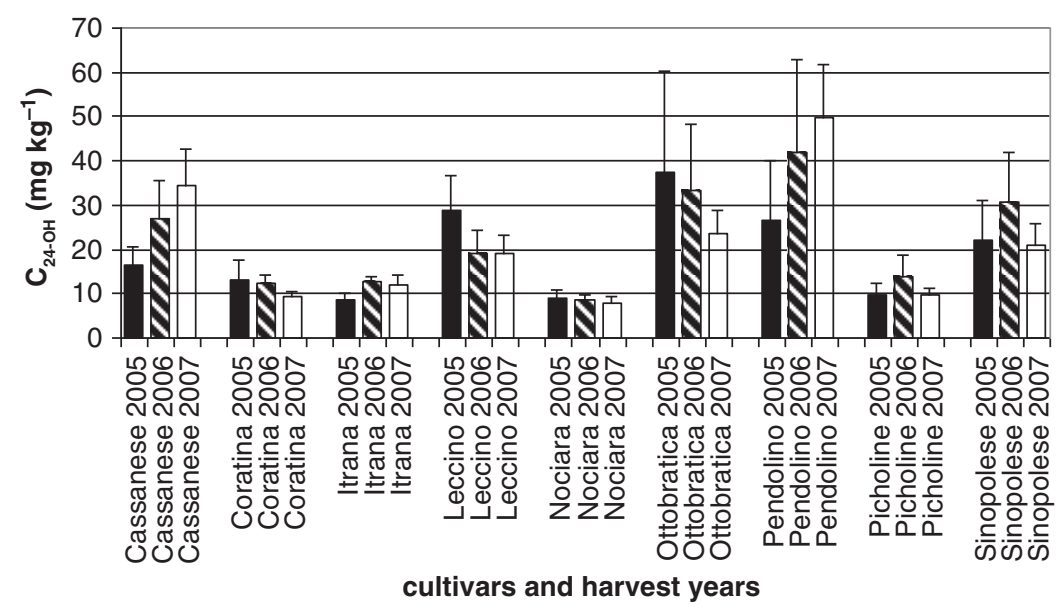

FIGURE 3. Variation in $\mathrm{C}_{24-\mathrm{OH}}$ contents for three harvest years 2005, 2006 and 2007, for the different cultivars. The values represent the means of five measurements \pm standard deviation. 
The effects of cultivar and harvest year on the fatty alcohol composition of olive oils from Southwest Calabria (Italy) 7

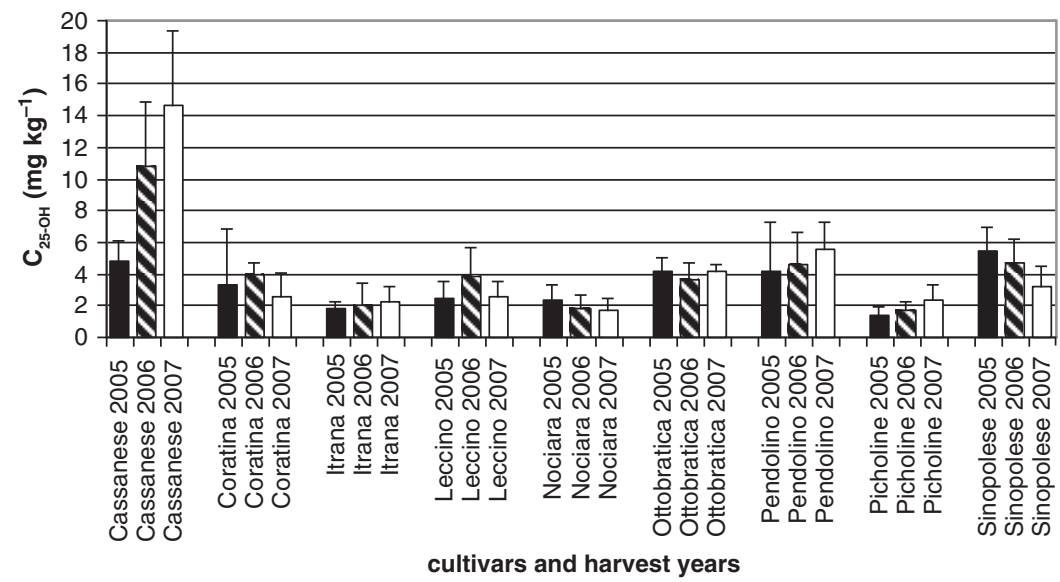

FIGURE 4. Variation in $\mathrm{C}_{25-\mathrm{OH}}$ contents for three harvest years 2005, 2006 and 2007, for the different cultivars. The values represent the means of five measurements \pm standard deviation.

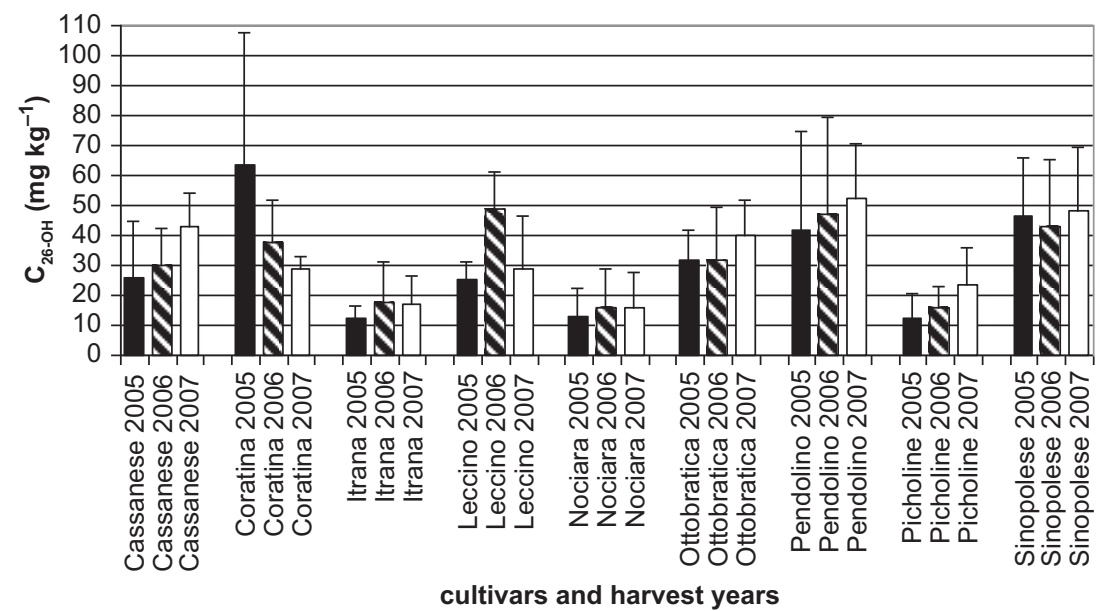

Figure 5. Variation in $\mathrm{C}_{26-\mathrm{OH}}$ contents for three harvest years 2005, 2006 and 2007, for the different cultivars. The values represent the means of five measurements \pm standard deviation.

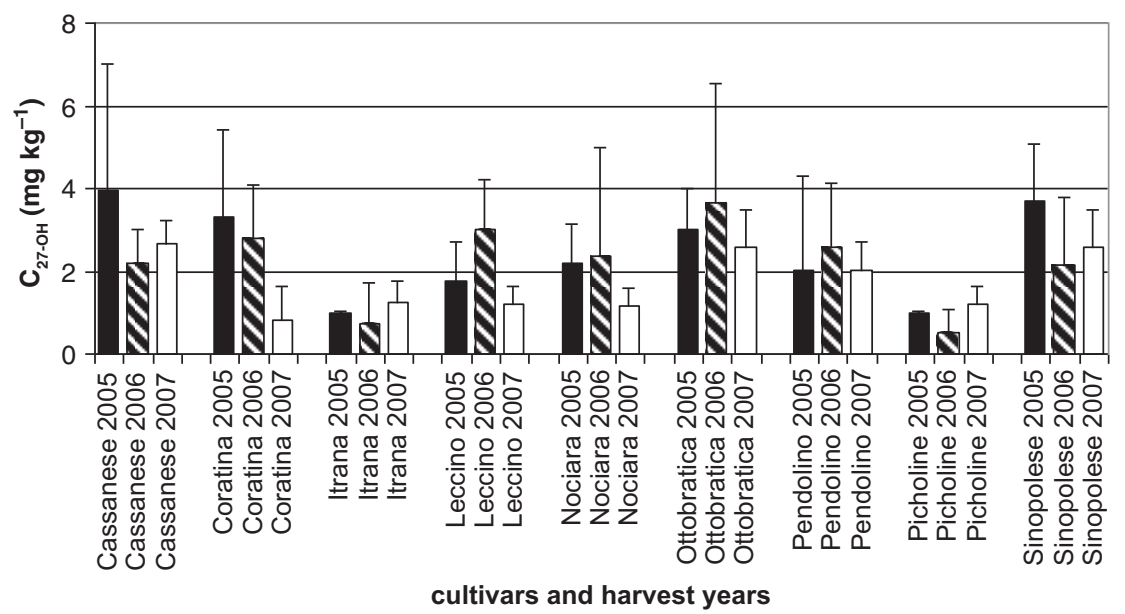

FIGURE 6. Variation in $\mathrm{C}_{27-\mathrm{OH}}$ contents for three harvest years 2005, 2006 and 2007, for the different cultivars. The values represent the means of five measurements \pm standard deviation. 


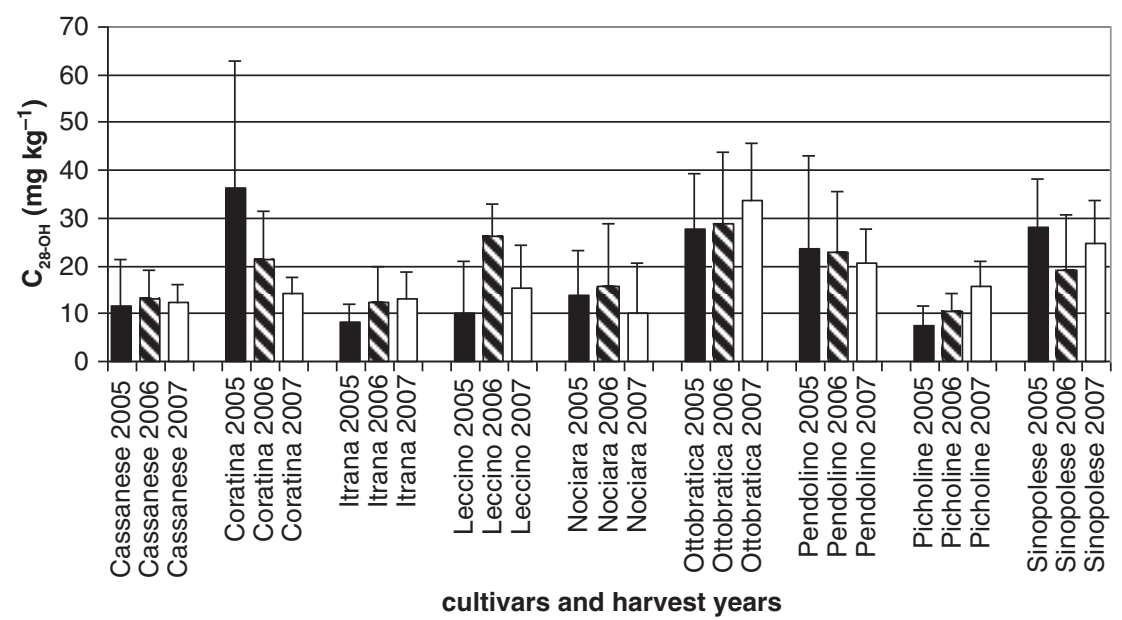

FIGURE 7. Variation in $\mathrm{C}_{28-\mathrm{OH}}$ contents for three harvest years 2005, 2006 and 2007, for the different cultivars. The values represent the means of five measurements \pm standard deviation.

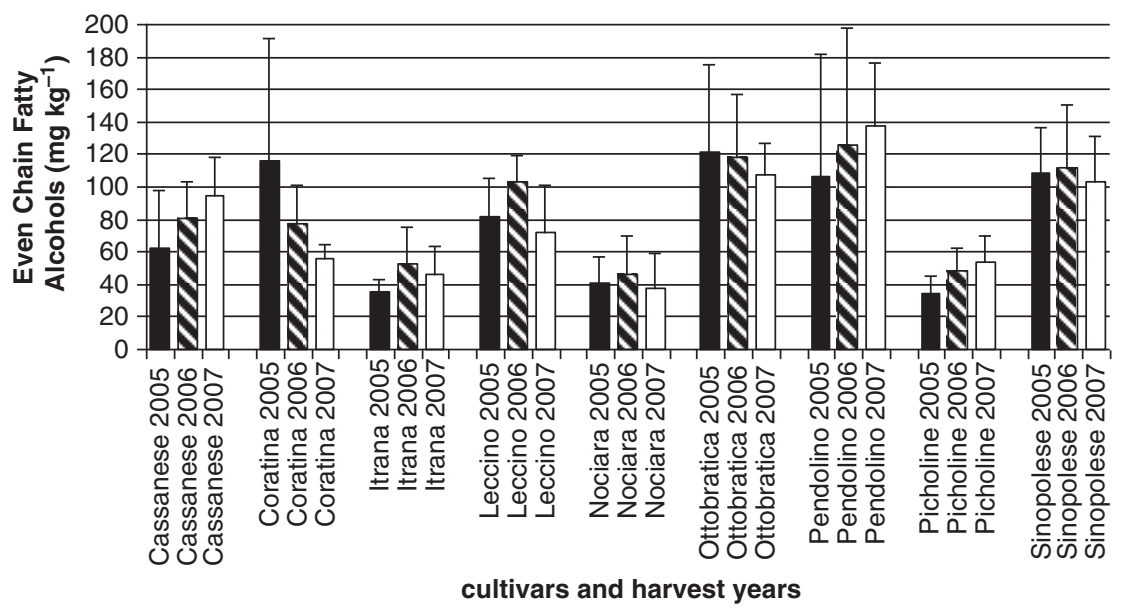

FIGURE 8. Variation in the sum of Even Chain Fatty Alcohol contents for three harvest years 2005, 2006 and 2007, for the different cultivars. The values represent the means of five measurements \pm standard deviation.

the same increasing trend found for hexacosanol and Coratina had the same decreasing trend. In Cassanese, Leccino and Nociara the highest octacosanol content was detected in 2006.

The variations in ECFALs and OCFALs are reported in Figures 8 and 9. The ECFAL and OCFAL contents increased in Cassanese, Pendolino and Picholine whereas it decreased in Coratina and Ottobratica during the three studied years. Consequently it can be seen that a similar trend was found for total FAL content (Figure 10).

In almost all cultivars the major value regarding the ECFALs/OCFALs ratio was found in 2006 (Figure 11).

\section{CONCLUSIONS}

The total amount of FALs determined in olive oils extracted from drupes of cultivars grown in Southwest Calabria (Southern Italy) was always well under $300 \mathrm{mg} \cdot \mathrm{kg}^{-1}$, allowing these oils to be classified as extra virgin, according to both EU and I.O.C. regulations. The FAL data for the allochthonous cultivars show a good adaptation to the microclimatic conditions of Southwest Calabria. FAL content in olive oil was highly influenced by cultivars. The combination of cultivar and harvest year showed an effect only in some cases. By and large, the harvest year had no effect on the FAL composition. 
The effects of cultivar and harvest year on the fatty alcohol composition of olive oils from Southwest Calabria (Italy) 9

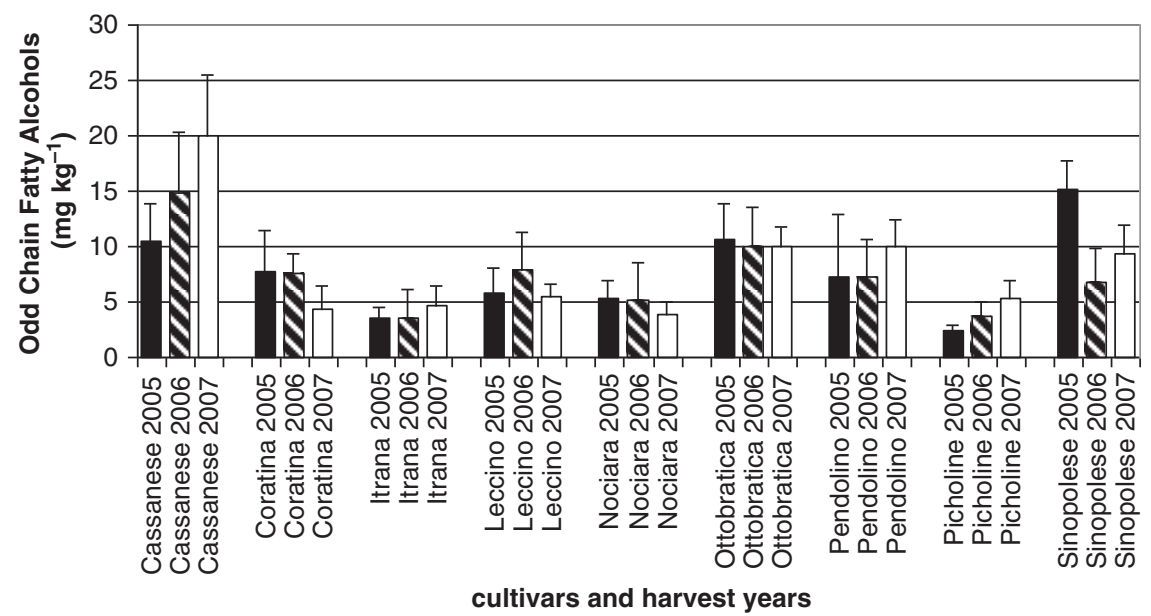

Figure 9. Variation in the sum of Odd Chain Fatty Alcohol contents for three harvest years 2005, 2006 and 2007, for the different cultivars. The values represent the means of five measurements \pm standard deviation.

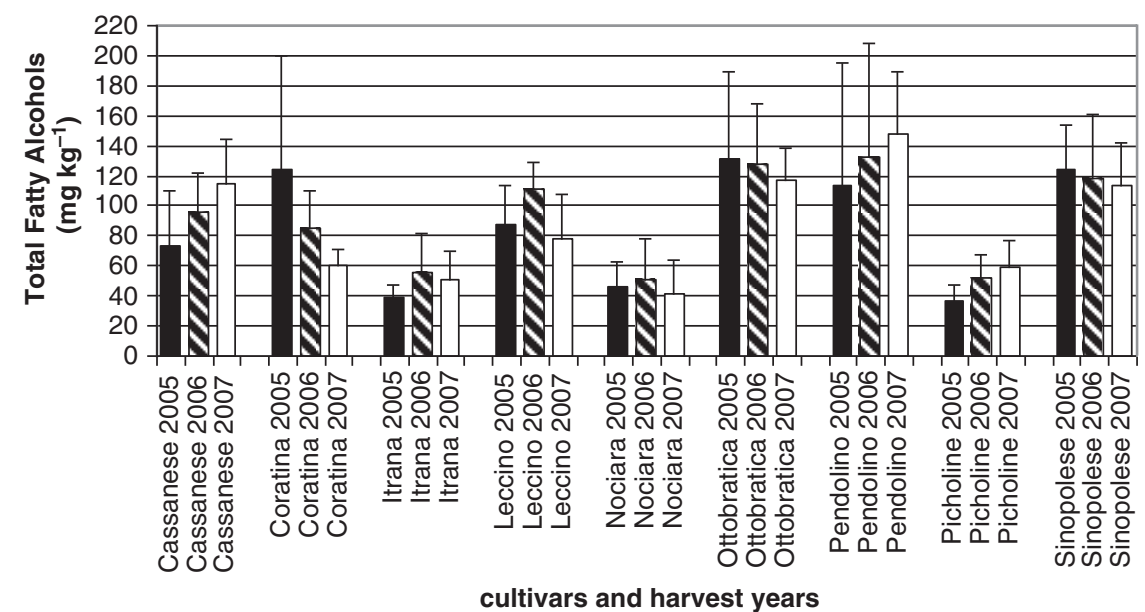

Figure 10. Variation in Total Fatty Alcohol contents for three harvest years 2005, 2006 and 2007, for the different cultivars. The values represent the means of five measurements \pm standard deviation.

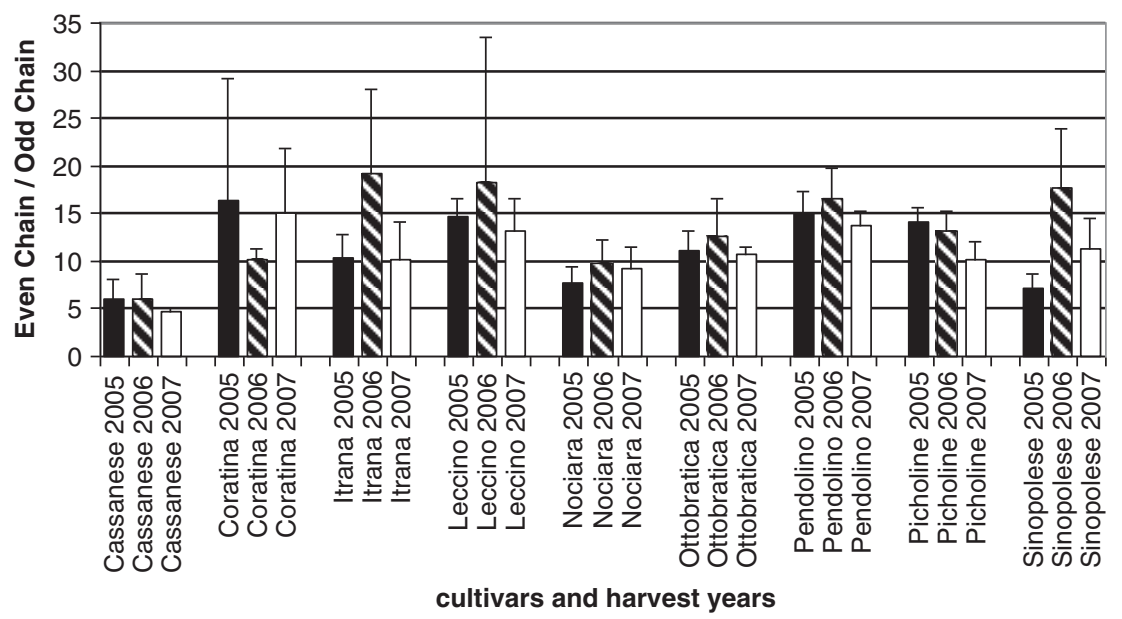

Figure 11. Variation in Even Chain Fatty Alcohol contents and Odd Chain Fatty Alcohol content ratio for three harvest years 2005, 2006 and 2007, for the different cultivars. The values represent the means of five measurements \pm standard deviation. 


\section{REFERENCES}

Aparicio R, Luna G. 2002. Characterisation of monovarietal virgin olive oils. Eur. J. Lipid Sci. Technol. 104, 614-627.

Consolidated text, CONSLEG: 1991R2568 - 01/11/2003, on the characteristics of olive oil and olive-residue oil and on the relevant methods of analysis, Annex XIX.

El Antari A, Hilal A, Boulouha B, El Moudni A. 2000. Influence of variety, environmental and cultural techniques on the characteristics of olive fruits and the chemical composition of extra virgin olive oil in Morocco. Olivae 80, 29-36.

EU. 2011. Commission Regulation (EU) No 61/2011 of 24 January 2011. Official Journal of the European Union.

Fernández-Arche A, Marquez-Martín A, de la Puerta Vazquez R, Perona JS, Terencio C, Perez-Camino C, Ruiz-Gutierrez V. 2009. Long-chain fatty alcohols from pomace olive oil modulate the release of protoinflammatory mediators. J. Nutr. Biochem. 20, 155-162.

Giuffrè AM. 2013a. Influence of cultivar and harvest year on triglyceride composition of olive oils produced in Calabria (Southern Italy). Eur. J. Lipid Sci. Technol. 115, 928-934.

Giuffrè AM. 2013b. Influence of harvest year and cultivar on wax composition of olive oils. Eur. J. Lipid Sci. Technol. $115,549-555$.

Giuffrè AM. 2012. Steroli, eritrodiolo e uvaolo in olio di oliva da cultivar cultivate in Calabria. Industrie Alimentari 51, 20-26.

Giuffrè AM, Louadj L, Poiana M, Macario A. 2012. Composition en stérols des huiles extraites d'olives de cultivars de la province de Reggio Calabria (Sud d'Italie). Riv. Ital. Sostanze Grasse 89, 177-183.

Giuffrè AM, Louadj L. 2013. Influence of crop season and cultivar on sterol composition of monovarietal olive oils in Reggio Calabria (Italy). Czech J. Food Sci. 31, 256-263.
Grob K, Lanfranchi M, Mariani C. 1990. Evaluation of olive oils through the fatty alcohols, the sterols and their esters by coupled LC-GC. J. Am. Oil Chem. Soc. 67, 626-634.

IOC. 2012. IOC/T.15/NC No 3/Rev.7. November 2012. Trade Standard Applying to Olive Oils and Olive-Pomace Oils.

Krichène D, Allalout A, Salvador M, Fregapane G, Zarrouk M. 2010. Fatty acids, volatiles, sterols and triterpenic alcohols of six monovarietal Tunisian virgin olive oil. Eur. J. Lipid Sci. 112, 400-409.

López-López A, Montaño A, Ruíz-Méndez MV, GarridoFernández A. 2008. Sterols, Fatty Alcohol and Triterpenic Alcohols in Commercial Table Olives. J. Am. Oil Chem. Soc. 85, 253-262.

López-López A, Rodríguez-Gómez F, Ruíz-Méndez MV, Cortés-Delgado A. Garrido-Fernández A. 2009. Sterols, fatty alcohol and triterpenic alcohol changes during ripe table olive processing. Food Chem. 117, 127-134.

Orozco-Solano M, Ruiz-Jiménez J, Luque de Castro MD. 2010. Ultrasound-assisted extraction and derivatization of sterols and fatty alcohols from olive leaves and drupes prior to determination by gas chromatographytandem mass spectrometry. J. Chromatogr. A 1217, $1227-1235$.

Ranalli A, Pollastri L, Contento S, Di Loreto G, Iannucci E, Lucera L, Russi F. 2002. Sterol and alcohol components of seed, pulp and whole olive fruit oils. Their use to characterise olive fruit variety by multivariates. J. Sci. Food Agric. 82, 854-859.

Strabbioli R, Bocci F, Frega NG. 2007. Qualità e stabilità dell'olio estratto dalle olive delle varietà marchigiane Piantone di Mogliano e Raggia a confronto con la cv Leccino. Riv. Ital. Sostanze Grasse 84, 125-132.

Taylor JC, Rapport L, Lockwood GB. 2003. Octacosanol in human health. Nutrition 19, 192-195. 